\section{Journal of the British Association for the Study of Religions}

JBASR 22 (2020), 55-70

ISSN: 2516-6379

\title{
The Impact of Social Media on Italian Shamanism and Folk Magic
}

\author{
Angela Puca \\ Leeds Trinity University \\ angelapuca@yahoo.it
}

\begin{abstract}
In the last decade, the use of social media has become widespread among all age groups in Italy. Facebook, in particular, has fostered the spreading of information and aided the gathering of like-minded individuals. This process has slowly but steadily affected communities involved with indigenous and transcultural shamanism. From the evolution towards a more inclusive and syncretic approach within autochthonous traditions to the wider reception and reinterpretation of imported shamanism, the narratives created online have translated into a tangible change of how practitioners position themselves within the affiliated tradition. By analysing data collected on a Facebook group I created ad hoc for my doctoral research and the content posted on public profiles and groups, I will argue that the use of Social Media reshapes the way practitioners construct their traditions and practices. In the case of vernacular healers, this prompted the development of a shared terminology while fostering a discussion on autenticity among trans-cultural shamans.
\end{abstract}

\section{KEYWORDS}

Segnature; shamanism; Italy; social media; vernacular healing; folk magic; trans-cultural shamanism; strega. 


\section{Introduction}

The advent of the internet and the increasing involvement of Social Media in the daily lives of Italians is showing a significant shift in how certain religious movements are evolving. Specifically, shamanism and vernacular healing have seen rapid evolutions in both the inner dynamics within practising communities as well as their ritualistic approaches.

In the present study, I will tackle trans-cultural forms of shamanism alongside the native healing tradition, which I have labelled in previous scholarship as the Tradition of Segnature and argued in my doctoral research to be the indigenous shamanism of Italy. ${ }^{1}$ As data gathered from fieldwork and social platforms online show, there is a trend leaning toward eclecticism and 'openness' even within those groups where secrecy used to be a founding element of their tradition. The way this trend is employed varies between the two strands of shamanism and yet they both appear headed towards an increasing sharing of rites, the tailoring of practices upon the individual, extending the field of action of their rites as well as a syncretism employed by borrowing from various spiritual and religious traditions.

However, while this increasing syncretism has brought autochthonous healers together it seems to be provoking - on online platforms - numerous altercations among trans-cultural shamans, especially with regards to the credibility of specific individuals and their practices. The matter of what can be legitimately defined as 'shamanism' is central to these discussions, which practitioners address by means of two main approaches, defined - in a later section - as a purist and an eclectic one. I will then conclude by offering my interpretation as to why there are opposing trends - unifying versus divisive emerging among online communities, depending on whether they belong to autochthonous or trans-cultural forms of shamanism

\section{How Social Media Unified an Underground Tradition}

The Tradition of Segnature is the label I adopt to systematise the Italian tradition of vernacular witchcraft that - despite the few regional variations - presents a strong common ground in its core practices, the Segnature. ${ }^{2}$ Translatable as 'Signs, gestures', the Segnature are a combination of words and gestures (crosses, in most cases) which are performed by vernacular witches, or Segnatori, ${ }^{3}$ for different purposes across the Italian peninsula (Bartolucci, 2016; De Bernardi, 2015). Most Italians, both from my personal experience and as emerged from my four years of fieldwork, are aware of these label-less figures. Usually addressed as 'The old man who fixes bones' or 'The woman who removes the evil eye', these magic practitioners are not openly talked about, unless someone trustworthy provides a reason to do so. Since I have covered this tradition in more details in my doctoral thesis and in a different article, I will

\footnotetext{
${ }^{1}$ I will leave this argument out of the present study, yet I needed to highlight that - in my understanding of the Italian scene - the two main strands of shamanism can be subdivided into 'indigenous' and 'trans-cultural.'

${ }^{2}$ Segnatura (female, singular), Segnature (female, plural). The noun has no male equivalent.

${ }^{3}$ Segnatore (male, singular), Segnatori (male/neutral, plural), Segnatrice (female, singulare), Segnatrici (female, plural).
} 
here focus on the impact that Social Media has had on this tradition and leave further details on the tradition out of the present discussion. ${ }^{4}$ There are three main significant changes occurred to the Tradition of Segnature as a result of the new ways of communication opened by the internet's usage: the creation of a cross-regional label (i.e. Segnature), a generational shift in how rituals are performed/transmitted and a preliminary acknowledgement of this tradition as a form of Italian shamanism.

As briefly mentioned above, vernacular healers in Italy do not have one consistently used label. Or so that was before the internet. Even though in Italian there are terms to translate 'witch', i.e. strega (female, singular) and stregone (male, singular), such terms have a negative connotation attached to them and only selected groups - mainly Pagans and occultists - adopt them as self-identifying labels. In the popular understanding, however, they are perceived almost as insults and hence avoided by those whose framework of reference is driven by the popular culture (Puca, 2019, 107; Magliocco, 2004, 162). Differently from Pagans and other esoteric practitioners who are actively involved in counter-cultural movements which reject the dominant views of their culture, folk magic practitioners may be seen as being immersed and somewhat endorsing - albeit in their own way - dominant cultural elements, including religious ones. As a result, these figures are only known by their community as 'the woman/man who cures X illness', identified not by names or labels but by the service they provide to those in need. ${ }^{5}$

Even the practice itself did not have a particular name, except in the Italian region Emilia Romagna, where the term Segnature was commonly adopted (De Bernardi, 2015). As reported in previous scholarship, I identify two generations within the Tradition of Segnature, each approaching the practice in significantly different ways: the 'old generation' and the 'new generation' (Puca, 2019, 111-117; Bartolucci, 2016, 76). Contrarily to what the terminology suggests, the different generational approaches are not strictly dependant on age but rather on whether they share/incorporate elements of the tradition with people outside of their bloodlines. As my field data showed, the less isolated the practitioner is - in their geographic or cyber space - the more they tend to share information, leading to a number of variations to the folk tradition passed down from their grandparents. The old generation is, in fact, the one which remains adherent to traditional vernacular elements and do not challenge nor bend any element of the rites, keeping them unaltered. This is not the case with the new generation of Segnatori, who share more openly what they have learned within their families and appear more incline toward altering the passed down practices by incorporating elements learned from other Segnatori of different regions.

This is a pattern found in most new religious movements and spiritual practices, where the wider the access to information is, the more eclectic a person or a tradition becomes (Chryssides, 2012, 53). When a person is only exposed to a limited amount of knowledge, linked to their culture or family, there is not really much of a choice to tailor a taught practice upon the individual inclinations. In a scenario where the pool of alternatives is varied, however, the

\footnotetext{
${ }^{4}$ The Tradition of Segnature is discussed in more details in Puca 2019.

${ }^{5}$ The central idea of being of service to the community has being highlighted by my informants in different interviews. For instance, those who were initiated by the well-known Sicilian healer Zia Checchina, emphasised how often she used to reiterate that concept.
} 
person is presented with both the choice and the chance to combine elements and make up their own practice instead of complying to what they were taught.

The access to the internet has rendered the circulation of information wider than ever, yet it is often the case that older people might not be familiar with its usage, hence lacking the possibility to find like-minded individuals from distant places with whom they could share elements of their tradition. In this sense, the generational gap may be related to the age of the practitioner, albeit not caused by it. Overall, If I had to narrow down the divide between the two generations to one core element, that would be isolation - geographic, cultural and cybernetic - which hinders the exchange of information with other Segnatori and hence the acknowledgment that a wider tradition exists beyond the boundaries of the individuals' community. This is the reason why online communities have revealed to be so key in the evolution of vernacular healing tradition towards a progressively perceived unity.

Over the past five years, with the increasing use of Facebook - the most popular social platform among Italians - a few online communities were created (Fattori, 2014, 20-40). The three most popular ones are 'Segnature, Magical Words, Green Magic' (Segnature, Parole Magiche, Magia Verde) which counts 11,410 members, 'Zia Checchina's Segnature' (Le Segnature di Zia Checchina) with 3370 members and 'Segnature, exorcisms, blessings' (Segnature, esorcismi e benedizioni) comprising 2934 members. ${ }^{6}$ The establishment of these online communities has created the need for a shared label, a term that Italians from all over the country could understand, and such a term is Segnature.

By analysing data collected from interviews and casual conversations, I realised that the adoption of this label trans-regionally first occurred thanks to vernacular healers who had moved from their birth place to a different city. This is the case of Maria Capasso ${ }^{7}$ and Michela C., two case studies covered in my doctoral thesis. Both women come from the South, respectively from the regions Sardegna and Calabria, and later moved to Toscana and Piemonte. It is also the case of the moderator of the aforementioned group 'Segnature, Magical Words, Green Magic', who is originally from Campania and now lives in Emilia Romagna. This is, in fact, a pattern I saw re-occurring among my informants, where moving far from their place of birth fostered the acknowledgement of vernacular healing practices as being Italian rather than regional. When this acknowledgment began to be shared on books - as in Michela C.'s case - or on Social Media - as in all three cases - such an understanding of local rituals as having a national background began to spread.

A significant trait of the Tradition of Segnature which aids our understanding of this dynamic is its underground nature. Since the old generation of vernacular healers were (and are) mostly Catholics, often dwellers of towns and small communities, they tend to be very secretive about their practices and employ a heavy syncretism with Catholic symbols and religious figures, such as the trinity and the saints. In addition, in the old generation every healer was only granted the 'power' (il potere) ${ }^{8}$ inherited by their blood relative. As a consequence, if their grandmother had the Segnature

\footnotetext{
${ }^{6}$ Names of Facebook groups and membership numbers were collected on the 2nd of July 2020 and are subject to change over time.

${ }^{7}$ All names in the present studies are pseudonyms chosen to protect the informants' identity.

${ }^{8} \mathrm{~A}$ term which re-occurred in interviews.
} 
to heal sprains and herpes, those would be the only ones they would be taught how to perform. With the new generation, however, I observed online and offline how the new Segnatori were exchanging their family's Segnature so that each healer would have multiple ones in their toolkit. Yet, when this exchange resulting from a wider communication beyond local boundaries does not occur, both the healer and the members of the community would only be aware of what their town healer is able to do and lack any awareness of similar practices being performed on a national level.

This was evidenced in multiple casual conversations and in a comment posted in June 2020 on the YouTube video I made to tackle the Tradition of Segnature. In the viewer's words,
$\mathrm{Hi}$, emilian guy from Modena's northern countryside here. I'm surprised to see a video that unfolds our 'folkloric' traditions. In my area it seems that the majority of segnatori are specialized in removing herpes zoster (which would eventually disappear, but many people are still convinced it speeds up the process). Also, I know of an acquaintance's grandpa who knows the 'segni', but I always thought of it as an anomaly, since from what I could gather the knowledge is preferably (if not, exclusively) passed down from woman to woman (at least where I live) (see Puca, 2020).

This comment describes quite accurately the reaction I have got from all the Italians who, as it happens in most cases, have only been exposed to local vernacular healers and hence believe the Segnature are a phenomenon which only occurs in their area and solely according to its regional manifestations. It is also important to notice that such regional variations are stronger in the old generation and are progressively fading with the new generation which employs a more national-based approach.

Thus, the scenario prior to the use of Social Media was that of widespread yet underground practices which - due to their strong secretive component - did not allow for a contextualisation in the wider national milieu. When this contextualisation actually occurred, thanks to online gatherings of Segnatori, practitioners acknowledged that people from different parts of the country were performing very similar folk rituals. As a result, the term Segnature began to be used more and more on Social platforms, to the point where almost every practitioner I have interviewed ${ }^{9}$ - who belonged to the new generation of Segnatori - was familiar with the term, regardless of their regional belonging. This is particularly relevant as the presence or absence of trans-regional communication revealed to be the decisive element in people's acknowledgement that the vernacular practices they had experienced were not isolated instances occurring in one place only but local manifestations of a wider folklore which shows similar patterns on a national level. This was a turning point for Italian folk witchcraft, one that the relatively recent use of Social Media has facilitated, creating a safe space for sharing personal experiences while developing a trans-regional conversation which may have never occurred otherwise.

\footnotetext{
${ }^{9}$ The total number of my informants is difficult to track as, in many cases, I gathered meaningful information from casual conversations occurred on the field. I can still estimate a rough number of 500 informants from the new generation of Segnatori. This includes practitioners whom I met in person, people who had received or are being healed by Segnatori and in online exchanges/interviews.
} 
Beside allowing Italian practitioners to see the wider framework whereby the Segnature operate, online communities have also fostered new ways of passing down and performing the Segnature, which combine traditional elements with contemporary needs. As a result, new Segnature were born, such as those to overcome the anxiety for a university exam, created by the combined effort of Segnatori who had inherited Segnature for similar issues. For instance, the 'fright' is traditionally treated by Segnature yet in different ways depending on the local interpretation and family traditions (De Bernardi, 2015, 219-222).

The modes of initiation were also altered by the use of social media. While traditionally Segnature are only passed down on a Christmas Eve's night to a (sometimes only one) blood relative, now Segnatori are passing down the Segnature through the internet, usually in private online communities. An example of this is Mara Verde, who posts the Segnature and the ritual to perform to activate them on her Facebook community for a few hours on every Christmas Eve's night, to then remove all the material when that sacred time is over. In an interview occurred in September 2018, Liliana D. explained how the online passing of the Segnature worked and how she performed all the steps in the ritual religiously. She did not see this procedure as any less sacred or valuable only because it was communicated on Facebook. On the contrary, she explained how grateful she was as - since she now lives in Switzerland - she would have not been able to access the knowledge and practice of the Italian Segnature otherwise.

The healing requests from people in need to the Segnatori also saw a development due to the pervasive use of Social Media. Now there are private online communities on Facebook where people can seek help from the Segnatori, who are often listed as such. The pattern that I saw occurring on a regular basis, and was confirmed by approximately a dozen of informants, is the following: the person needing help would post their request on the community, one of the Segnatori would reply either to redirect the person to another healer specialised in that condition or to invite them to send a private message with key information (name and date of birth) and a photo of the person and/or of the affected part of their body. Often people seek help on the behalf of loved ones, getting the same kind of response. The online Segnatori typically offer their help free of charge and deem this practice as a sacred or a holy responsibility.

Although most of those belonging to the old generation were Catholics, the new generation sees a large number of Pagans as well as Segnatori who engage with other alternative spiritualities, such as shamanism, Reiki, ho'oponopono, et similia (Bartolucci, 2016). This shift in religious or spiritual affiliation has also impacted the practice of Segnature as those who have left the Catholic faith will not feel comfortable with adopting Catholic elements into their practice. In such cases, they might perform the initiations on the Winter Solstice instead of Christmas Eve and either remove the references to Catholic sacred figures or replacing them with pre-Christian deities. An example of this is Celeste B., a young woman from the Campania region whom I interviewed in December 2017, who identifies as a Pagan and shared her struggles in carrying on her grandmother's tradition due to the heavy elements of Catholicism. Federica C., Core Shamanism practitioner and Segnatrice from Emilia Romagna, explained in an interview in May 2018 that she will carry out 
initiations on Winter Solstices to better suit her beliefs. Lastly, Michela C. from the region Calabria, told me that her Segnature involve the Etruscan deity Uni while advocating that pre-Christian Segnature are greatly effective and older than the Christian ones. What the engagement with communities on the internet has produced here is not only the possibility of new forms of syncretism to reflect the changing beliefs within the Italian society but has also reassured so to speak - those who valued a family inherited tradition that they could carry it on according to their own belief system. The experiences shared by other new Segnatori have proven to their peers that such an approach can, in fact, be just as valid.

In summary, the more vernacular witches are in communication with peers from different regions of the peninsula, the more they manifest an acknowledgement of their rites as belonging to a nationally-based folklore, rather than locally or family-based. Consequently, practitioners are acquiring progressively more elements to evaluate this set of practices and discern its traits, both in relation to the tradition itself and in how it relates to other religiousspiritual movements. An example of this is the discussion around whether what I call the Tradition of Segnature can be deemed as a form of Italian shamanism.

Interestingly, in a similar way as with the label Segnature, the first vernacular healers who advanced the idea that the practice of Segnature is a form of shamanism are two Southern women who moved to the North of Italy, Maria Capasso and Michela C. In my doctoral thesis, I argued that in the Western world a romanticised and exotic understanding of shamanism has, so far, prevailed in the popular understanding of this category. Thus, only healing rituals which belong to faraway countries with perceivably exotic cultural features are deemed to be shamanism in the popular understanding. Such a preconception may, therefore, hinder the acknowledgment of a form of shamanism in a European country even when shamanistic traits do manifest as part of a local tradition. Previous scholarship has, in fact, highlighted this romanticised and exotic understanding of shamanism on the part of Westerners (Wallis, 2003; Jakobsen, 1999; Johnson, 1995; Atkinson, 1992; Porterfield, 1987).

Interestingly, it is the 'exoticising' distance created by leaving one's home-land that will reproduce that same romantic outlook on otherwise mundane - superstitious even - folkloric rites. This is especially the case, when Southern practices are seen from the perspective of a more industrialised North of the country, where some people still hold on the preconception that the South is more rural and endorses pre-Enlightenment worldviews (Pell, 2010; Lupo, 1998).

There are, therefore, two main conditions whereby practitioners acknowledge the Segnature as part of an Italian tradition, leading to further speculations on its nature and possible categorisation within the religiousspiritual milieu. The first is a trans-regional network which leads the individual to see the wider picture and recurring patterns showed by these practices across the country. A second condition seems to be overcoming preconceived misrepresentations of certain labels, in order to foster the categorisation of a newly acknowledged tradition. 
A striking example of this is given by the discourses created by the Praticanti di Sciamanesimo in Italia created a poll.

- Admin $30 \mathrm{Jan} \cdot$ 国

Buongiorno a tutti,

Domanda importante per voi, amici.

Le pratica delle Segnature italiana può essere considerata una forma di Sciamanesimo?

Spiegate la vostra motivazione nei commenti, se vi fa piacere!

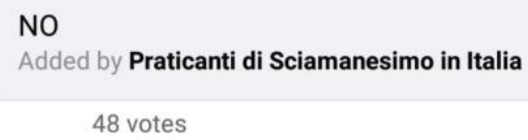

SI

Added by Praticanti di Sciamanesimo in Italia 48 votes

solo se chi la pratica ha doni sciamanici e lo dimostra

Added by Manuela $\mathbf{C}$

7 votes
... community on whether the

Segnature can be seen as shamanic practices. On the $30^{\text {th }}$ of January 2020, I opened a poll on my research-led Facebook group 'Practitioners of Shamanism in Italy'. The poll asked members of the group (see figure 1) whether they thought the Italian practice of the Segnature could be considered a form of shamanism. The responses were not only interesting in themselves but also in how the trend changed depending on the absence or presence of a conversation among people from different regions. In the beginning, the most popular response was 'No', with three fourths of respondents' selection. After Manuela C. added the third option 'Only if the person who performs [the Segnature] proves to have shamanic gifts' and a discussion emerged in the comments, the trend started to

Figure 1. Facebook Poll

shift. Soon after there was a slight majority choosing 'Yes' while over time it settled at an equal number of members selecting 'Yes' as those opting for 'No'. Although it is significant to notice that the third option is affirmative in nature, which leads to the conclusion that out of a total of 103 respondents, 55 deemed the Segnature to be a shamanic practice as opposed to the 48 members who disagreed.

This shows how undefined, in the minds of practitioners, are both the definition of what constitutes shamanism and the practice of Segnature. The community is, therefore, not yet at the stage where they discuss settled concepts, but still in the process of constructing and negotiating their meaning in an attempt to find agreed-upon definitions. Such a process is not only facilitated by online engagement in social communities but - at least in part created by it. Had there not been these groups on Social Media, the large majority of Segnatori might have never realised that those practices were not exclusive to their family or town, but part of a wider phenomenon. The web of information exchange stemmed from online communities has allowed a slow and progressive emersion of a tradition, which had been - up until then - hidden in plain sight for its perceived outlier nature, belonging to one place only and not a manifestation of a larger movement. Every vernacular healer thought 
themselves to be a stand-alone piece all the while settled in a puzzle that the internet has uncovered.

\section{Trans-cultural Shamans Online and the Divisive Pursuit of Validation}

If the Tradition of Segnature is what I have elsewhere argued to be the indigenous Italian shamanism, its counterpart can be seen in trans-cultural shamanism. By 'trans-cultural shamanism' I mean to encompass all those traditions and groups which do not engage in practices of Italian descent but with either reinterpretations of imported shamanisms or Western-born traditions which are cross-cultural in nature. The most popular manifestation of the latter kind, which also embodies and fosters the overall trends found across transcultural traditions, is Core Shamanism. Founded by the American anthropologist Michael Harner, Core Shamanism endorses the idea that the different indigenous shamanisms all share the same core elements. Such elements are found cross-culturally and hence are not deemed to be dependent on one specific culture but rather belong to humankind as a whole, regardless of one's location or traditional heritage (Harner, 1982; Foundation for Shamanic Studies, n.d.).

Over the decades, the approach and techniques popularised by Core Shamanism representatives allowed this Western-born tradition to become the most popular form of shamanism in Italy. It is significant to highlight that Castaneda's books have been the primary gateway for Italians in the past decades while, once the interest was ignited, Mircea Eliade would offer a theoretical framework whereby to define shamanism (Casadio, 2014; Eliade, 1972; Castaneda, 1968). Eliade moulded the definition of shamanism that the average Italian practitioner still upholds while Castaneda offered the model of the encounter between the Western secularised and rational mind with what had been imagined as a less-rational set of beliefs and practices. Both models of interpretation have fostered a romanticised idea of the shaman as a mystical figure in contact with the spirit world while preserving an 'exotisation' of the peoples and cultures to whom shamanism belong.

As a consequence, shamanism can rightfully exist only in non-Western cultures which had not gone through the 'disenchantment of the world' that occurred after the Enlightenment (von Stuckrad, 2014). Such a belief endorsed by the average Westerner - has led to the creation of Western-born forms of shamanism, which focus on the techniques rather than on the nonWestern cultural-specific features of shamanic traditions. Trans-cultural shamanism, sometimes also referred to as 'neo shamanism,' is hence a set of traditions found in Western countries whose practices are neither linked to nor dependent on specific cultures or places to which the practitioner needs to belong. As highlighted by Johnson (1995) and Atkinson (1992) - just to name a few - one of the main traits of this kind of shamanism is a belief in the universalism of the practice since anyone from any place or culture can engage in shamanic practices. This concept of universalisation and its related cultural self-determination possibly stems from the idea, often endorsed by transcultural shamans, that shamanism is a proto-religious movement. In line with Mircea Eliade's view of the shaman as the master of the 'archaic techniques of ecstasy,' most practitioners deem shamanism as the oldest foundation from which all forms of religiosity were born (Eliade, 1972). 
Interestingly, while Social Media usage has prompted the creation of a community for the Segnatori along with the acknowledgment of a unity underlying local practices, for trans-cultural shamanic practitioners the trend goes in the opposite direction or, at least, seams to cultivate a divisiveness of sort. Among trans-cultural practitioners it is, in fact, very common to witness altercations on a regular basis as well as heated discussions on one topic or another. Usually, such altercations hover around the matter of 'authenticity,' what is 'real' shamanism and who is entitled to adopt the term to define their practices. On this matter, there are two main approaches adopted by practitioners, which I will define as an 'eclectic' and a 'purist' one. Although most practitioners fall somewhere in this spectrum - of which eclecticism and purism represent polar opposites - those who start or engage in these online arguments tend to lean more towards one of the two ends.

The purist approach is adopted by those who believe that what someone practises is 'real shamanism' insofar as it meets certain specific criteria. These can range from adhering to Mircea Eliade's description of shamanism to being initiated by an indigenous shaman or having lived among indigenous peoples for a length of time. The hidden narrative here is that shamanism is something very defined, a set of techniques to enter trance states which belong to indigenous cultures. This understanding of shamanism will consequently exclude all forms of cross-cultural shamanism born in or developed by Western countries. By contrast, the eclectic approach is endorsed by practitioners who are usually well versed in cross-cultural practices inspired by Castaneda's or Mamani's ${ }^{10}$ works as well as by Core Shamanism. They also believe that shamanism is a set of ecstatic techniques but they are open to incorporating elements from a number of indigenous traditions and/or experiment with nonlocal based practices.

What data collected from the Facebook group 'Practitioners of Shamanism in Italy' shows in that there is a recurring theme of credibility along with whether the person or their practice are to be deemed 'true shamanism.' There have been numerous discussions on the matter and I will report a few of them, selecting the most representative of the variations surrounding such debate.

On the $3^{\text {rd }}$ of February 2018, Serena P. posted the programme for her coming workshop in the group, which prompted a discussion on whether a 'real shaman' would ask for a payment to bestow their teachings. Emilia P.'s comment shows an example of the point of view of those who oppose the idea that participants would have to pay for a shamanic training. In her words,

If you pay, they are not true shamans or teachers. Shamans have a gift, which they offer in exchange for offerings. My advice is to be wary if you want to approach the spiritual path with open heart and genuine interest. If you have to pay for it, don't do it. ${ }^{11}$

\footnotetext{
${ }^{10}$ Hernán Huarache Mamani (1943-2016) was a Peruvian shaman and writer whose books and workshops have become very popular in Italy in the past decades. La Profezia della Curandera (translatable as 'The Prophecy of the Curandera') is a best seller book and has drawn many of its readers to shamanism, especially women. Mamani's works tend, in fact, to have a focus on the divine power of the feminine (Mamani, 2014).

11 'Se si paga, non sono veri sciamani o Maestri. Gli sciamani che hanno un dono, offrono tale dono e accettano al massimo offerte. Diffidate. II mio è un consiglio per chi con il cuore e con
} 
This is a recurring narrative, which follows both the dichotomy between the material and the spiritual world - fostered by the New Age movement according to which the spiritual is deemed above and beyond the necessities of the physical world, and a romanticised idea of the shaman as this mystical figure who follows a spiritual path and, as such, is believed to have a lack of interest in material possessions.

In a different post emerged another recurring point of discussion, that is whether shamanism can be eclectic or not. On the $2^{\text {nd }}$ of January 2018 , a known representative of Druidry in Italy posted the advertisement for a talk which would have taken place at the Popular University of Biella (Università Popolare Biellese APS). The digital flier posted on the group read 'Celtic Shamanism. Druidry as a philosophy of living' (Sciamanesimo Celtico. II Druidismo come Filosofia di Vita). This post caused a reaction from another member of the group which escalated to such a heated argument that the Druidry representative decided to leave the group. Mauro N.'s point of view can be summarised below, in his own words,

Defining Druidry as Celtic Shamanism is anachronistic and absolutely misleading [...] The fact that there are liaison points does not mean that the two are the same. There are no historical, archaeological or mythological elements to uphold that Druidry is a form of Shamanism. It would be enough to highlight that in Druidry there's a choice to join in and not the Call or the fact that there is a religious establishment to understand that Druidry and Shamanism are two different things. ${ }^{12}$

It is relevant to highlight that Mauro $\mathrm{N}$. follows an indigenous form of shamanism to which he has claimed on multiple occasions to have been initiated and has engaged in a number of similar altercations on other posts to oppose shamanism in its trans-cultural manifestations. This would be the approach that I have previously defined as 'purist,' whereas the representative of Druidry was offering a more eclectic view of shamanism while clarifying the liaison points between the latter and the Druid practice. What a purist would deem to be shamanism is well explained in the following example, where there is - once again - a portrayal of the shaman as both detached from economical profits and linked to one specific lineage or tradition. The propensity to tailoring the practice upon individual inclinations is hence seen as lacking credibility and as a misguided 'DIY.' On the $26^{\text {th }}$ of November 2018, Marco N. posted his lengthy argument on the credibility of a shamanic practitioner,

The practitioner of modern times must necessarily be linked to a very specific Tradition and its spiritual-religious forms, assuming the burden of the Investiture and carrying out ALL the Practices related to the Shaman, such as the extraction of negative energies, the recovery of Fragments of the Soul, the action of a psychopomp, or to operate for the fertility of the individual or the Family-Group to which they belong

\footnotetext{
interesse si vuole interfacciare ad un percorso spirituale. Se si paga, non accettate.' Translation is mine.

12 'Definire il Druidismo, Sciamanesimo Celtico è anacronistico e assolutamente fuorviante [... II fatto che esistono punti di contatto non vuol dire che le due cose siano assimilabili. Non esistono elementi storici, archeologici o mitologici che affermino che il Druidismo sia Sciamanesimo. Basterebbe evidenziare la scelta e non la Chiamata o l'organizzazione in una casta religiosa per capire che Druidismo e Sciamanesimo sono 2 cose diverse.' Translation is mine.
} 
[...] A service that is not aimed at making money or making it a profession, assembling - to profit from it - activities that have nothing to do with the shamanic practice and that significantly reduce the person's credibility. Likewise, credibility is lost when you say you're not a Shaman while claiming to do the same specific operations delegated to this role. ${ }^{13}$ The 'I do it all by myself' does feature neither with the Shaman nor with the Practitioner who has made this Way his Way. Nor is it credible to deal with two different paths (let alone three or four ...), unless one of the two is only studied academically. ${ }^{14}$

The theme of authenticity is not only shown in altercations among group members as it also surfaces within the community in the form advice - sought or given - on what it is credible and worth following, attending or studying. Exemplary of this pattern is a request posted by Don G. on the $21^{\text {st }}$ of April 2020. As a former Reiki practitioner, now new to shamanism, Don was seeking advice on online workshops to undertake and books to read. Two representatives of trans-cultural shamanism shared their advice, which I report as in line with previous recommendations given to similar posts and hence representative of a trend. Chiara $\mathrm{C}$. writes,

Forget about online courses and video courses. Check carefully the 'CV' of the person you are addressing (training and experience, not fame, they are not always the same thing), avoid those who perform 'activations' and 'initiations,' always ask one more question rather than one less. ${ }^{15}$

Fabrizio V. then added,

As Chiara has already told you, pay close attention to the qualifications of the teacher, check what she has studied and with whom, preferably verifiable names and surnames and not a generic 'native shaman' or variations on this theme. Unfortunately, shamanism is now in fashion and there is a plethora of charlatans around who only aim to make

\footnotetext{
${ }^{13}$ Clear reference to Core Shamanism practitioners, who do not call themselves 'shamans' but 'practitioners of shamanism' out of respect for this role as believed to belong to indigenous cultures.

14 'L'Operatore dei tempi moderni dovrà necessariamente essere legato ad una Tradizione ben specifica e alle sue forme spirituali-religiose, assumendosi l'onere dell'Investitura ed espletando TUTTE le Pratiche connesse allo Sciamano, come l'Estrazione di energie negative, il Recupero di Frammenti dell'Anima, l'azione da psicopompo, od operare per la fertilità del singolo o della Famiglia-Gruppo di appartenenza [...]

Un Servizio che non è teso a lucrare nè a farne una professione, assemblando per esigenze economiche attività che nulla hanno a che vedere con la Pratica sciamanica e che riducono sensibilmente la credibilità dell'operatore, così come la stessa credibilità viene meno quando si asserisce di non essere uno Sciamano, ma si sostiene di fare le stesse specifiche operazioni delegate a questo. II "faso tutto mì" non si sposa né con lo Sciamano, né con il Praticante che ha fatto di questa Via la sua Strada. Né è credibile affrontare in modo evolutivo due Strade diverse tra loro (figuriamoci tre o quattro...), a meno che una delle due non sia solo di studio accademico.'

15 'Lascia perdere i corsi online e i videocorsi. Controlla bene il "cv" della persona a cui ti rivolgi (formazione ed esperienza, non fama, non sono sempre la stessa cosa), evita chi faccia "attivazioni" e "iniziazioni", poni sempre una domanda in più piuttosto che una in meno.' Translation is mine.
} 
money and gratify their ego. Unfortunately, I find myself forced to say that this group is exemplary in this regard. ${ }^{16}$

Overall, what emerges is that the use of Social Media has had a somewhat divisive effect among trans-cultural practitioners, due to issues surrounding legitimacy of one's shamanism and the credibility of the individual. It is, in fact, relevant to notice that this dynamic of search for validation of one's own practices as shamanism is present both offline and online. However, during face-to-face gatherings of shamanic practitioners, I have never witnessed any altercation of the sort. While the discussions over what constitutes shamanism may still arise, there is no divisiveness nor heated arguments when practitioners are addressing the matter in person.

\section{Conclusion}

The use of Social Media has had a significant impact on both the autochthonous vernacular healing and trans-cultural shamanism in Italy. However, as preliminary data shows, it appears that for the vernacular healers the trend is of a unifying nature whereas for trans-cultural shamans a divisive search for validation seems to prevail. These almost antithetical tendencies might be due to two main traits which differ between the two strands of shamanistic manifestations. First, folk healers do not charge for their help nor do they host public workshops to teach their practices. When they decide to help someone or share their knowledge with somebody, it is usually for free and hence there is no competition arising among different healers. On the other hand, transcultural shamanism is known for the wide array of seminars, training and workshops it offers. Having a structured organisation, a venue and commodities for the practice involved, they do charge to enrol in such courses. The latter element, along with the increasing offer of shamanic workshops on the peninsula, leads to a competition of sort among the practitioners and hence to a needed metric to evaluate which of those may be valid sources of knowledge.

The second element which might play a role is that the Tradition of Segnature is still in the process of acknowledging a national unity across different regions and the perception of it being a tradition in and of itself is still in its preliminary stage. Differently, trans-cultural shamans tend to have a much clearer - albeit varying on individual beliefs - idea of what shamanism is. The category per se is there, a reified subject which can be analysed and discussed. When the very subject matter is not even defined for those who partake into a conversation around it, the narratives will still move toward finding a common ground rather than arguing around which trait should be deemed more important.

Not only is 'shamanism' a reified category that allows practitioners to argue around its meaning, but also a fashionable and desirable label for one's tradition to get social approval. Differently from other religious movements departing from the dominant religious system, shamanism is - in fact - neither

\footnotetext{
16 'Come giustamente ti ha già detto Chiara fai bene attenzione alle qualifiche dell' insegnante, verifica cosa ha studiato e con chi, preferibilmente nomi e cognomi verificabili e non un generico "sciamano nativo" o variazioni su questo tema. Purtroppo adesso lo sciamanismo è di moda e c'è una pletora di ciarlatani in giro che puntano solo a fare quattrini e gratificare il proprio ego. Sfortunatamente mi trovo costretto a dire che questo gruppo è esemplare a questo riguardo.' Translation is mine.
} 
demonised nor perceived as a threat by the Catholic church, for its perceived status of non-religious or proto-religious harmless practice (Puca, 2018, 278280). As a result, it has become a valuable label to those who do not want to see their practices rejected by the average person. This applies to both autochthonous and trans-cultural shamans, albeit the latter are the ones who employ the term the most. In the few cases where a Segnatore refers to his or her tradition as a form of shamanism, they tend to be confronted with the same hostility as they enter the heated discussion around 'true shamanism' and whether X practice can be deemed as such. This was shown in a couple of recent posts on the Facebook group 'Practitioners of Shamanism in Italy,' where Manuela C. portrayed her Sardinian healing tradition as shamanism. On the $18^{\text {th }}$ of July 2020, Maria Capasso published a post on how to engage with the Saints according to Sardinian shamanism and Giovanni M. commented by challenging her definition of the vernacular tradition as shamanism, which led to an altercation on the matter. Maria Capasso engaged into a long discussion on the matter and - later that day - posted the cover of a book by the Italian folklorist Dolores Turchi, Lo Sciamanesimo in Sardegna ('Shamanism in Sardinia'), to back up her point. It is also relevant to highlight that, even though Maria comes from a lineage of Segnatori, she has also been part of the transcultural shamanic community for decades. This led her to acknowledge the shamanic nature of her family tradition, as she explained in an interview conducted on the $9^{\text {th }}$ of May 2019, but also affected the modalities whereby she presents her practice to the public sphere. Maria leads workshops and seminars and syncretises the Segnature with other trans-cultural healing practices, such as Core Shamanism and other holistic healing techniques. What this example shows is that the divisiveness is not embedded in transcultural practices but rather surrounds the category of shamanism, for both its meaning - which lacks an agreed-upon consensus (Hutton, 2006, 209) - and its desirability, since it would allow outliers to avoid encountering public disapproval (Puca, 2018, 278-280).

It is also significant to highlight that the two trends here presented are those emerging from present day usage of Social Media platforms, leaving out of the discussion the past occurrences which have - in some cases - led to the current state of things. For instance, trans-cultural shamanism has seen itself a unifying tendency when it first began to spread, both in the country and on online communities. However - with the proliferation of groups, traditions, events and workshops - the trend I analyse in the present study arose among practitioners as a way to construct a set of criteria to categorise the wide variety of shamanic groups on the peninsula. In this light, what I have covered in this study needs to be seen in relative terms rather than as absolute traits of the tackled traditions. These are indeed trends relative to the referenced time, the evolution stage of each analysed tradition and the extent of acknowledgement of each tradition on a national scale. I would expect these dynamics to change at a rapid pace as this is, in fact, the kind of tempo marked by inhabiting the virtual - yet very real - world of Social Media. 


\section{References}

Atkinson, J. M. (1992) 'Shamanisms Today', Annual Review of Anthropology, vol. 21, pp. 307-330.

Bartolucci, A. (2016) Le streghe buone. I simboli, i gesti, le parole. Come muta la medicina tradizionale nell'era di Internet, Reggio Emilia, Compagnia Editoriale Aliberti.

Casadio, G. (2014) Lo sciamanesimo. Prima e dopo Mircea Eliade, Roma, II Calamo.

Castaneda, C. (1968) The Teachings of Don Juan: A Yaqui Way of Knowledge, Berkeley, CA, University of California Press.

Chryssides, G. D. (2012) Historical Dictionary of New Religious Movements, Plymouth, Rowman \& Littlefield.

De Bernardi, M. (2015) 'Segnare la guarigione: etnosemiotica di un atto magico : lettura semiotica della pratica delle "segnature" nella prospettiva tranculturale relativa alla zona degli Appennini della regione italiana dell'Emilia Romagna', Phd thesis, Université Toulouse le Mirail Toulouse II [Online]. Available at https://tel.archives-ouvertes.fr/tel01326386/document (Accessed 2 March 2018).

Eliade, M. (1972) Shamanism: Archaic Techniques of Ecstasy, Trask, W.R. (trans), Princeton, NJ, Princeton University Press.

Fattori, G. (2014) Social media e promozione della salute, Giuseppe Fattori.

Foundation for Shamanic Studies (n.d.) Core Shamanism Official Definition [Online]. Available at

https://www.shamanism.org/workshops/coreshamanism.html (Accessed 24 October 2019).

Harner, M. (1982) The Way of the Shaman, Bantam Edition, New York, Harper \& Row.

Hutton, R. (2006) 'Shamanism: Mapping the Boundaries', Magic, Ritual, and Witchcraft, vol. 1, no. 2, pp. 209-213 [Online]. DOI: 10.1353/mrw.0.0050.

Jakobsen, M. D. (1999) Shamanism: Traditional and Contemporary Approaches to the Mastery of Spirits and Healing, Reprint edition, New York, Berghahn Books.

Johnson, P. C. (1995) 'Shamanism from Ecuador to Chicago: A Case Study in New Age Ritual Appropriation', Religion, vol. 25, no. 2, pp. 163-178 [Online]. DOI: 10.1006/reli.1995.0015.

Lupo, S. (1998) 'Storia del Mezzogiorno, questione meridionale, meridionalismo', Meridiana, no. 32, pp. 17-52.

Magliocco, S. (2004) 'Witchcraft, healing and vernacular magic in Italy', in Blecourt, W. de and Davies, O. (eds), Witchcraft Continued: Popular Magic in Modern Europe, Manchester, New York, Manchester University Press, pp. 151-173.

Mamani, H. H. (2014) La profezia della curandera, Place of publication not identified, Sperling \& Kupfer.

Pell, G. (2010) 'Terroni di mezzo: Dangerous physiognomies', in Russo Bullaro, G. (ed), From Terrone to Extracomunitario: New Manifestations of Racism in Contemporary Italian Cinema: Shifting Demographics and Changing Images in a Multi-cultural Globalized Society, Leicester, Troubador Publishing Ltd, pp. 178-218. 
Porterfield, A. (1987) 'Shamanism: A Psychosocial Definition', Journal of the American Academy of Religion, vol. 55, no. 4, pp. 721-739.

Puca, A. (2018) "Witch" and "Shaman": Discourse Analysis of the Use of Indigenizing Terms in Italy', International Journal for the Study of New Religions, Indigenizing Movements in Europe, vol. 9, no. 2, pp. 271-284.

Puca, A. (2019) 'The Tradition of Segnature: Underground Indigenous Practices in Italy', The Journal of the Irish Society for the Academic Study of Religions, no. 7, pp. 104-123.

Puca, A. (2020) Italian Contemporary Witchcraft. The Tradition of Segnature. [Online]. Available at https://www.youtube.com/watch?v=il1XkmZLWgE\&t=407s (Accessed 10 May 2020).

von Stuckrad, K. (2014) The Scientification of Religion, Boston, Berlin, De Gruyter.

Wallis, R. J. (2003) Shamans/Neo-Shamans: Ecstasies, Alternative Archaeologies and Contemporary Pagans, London, New York, Routledge. 